\title{
Community engagement in developing urban design guidance for heritage sites: The case of Bursa, Turkey
}

In recent years, central and local governments have carried out studies to establish a legal administrative infrastructure for urban design and to develop urban design guidance to preserve the identity of historic cities under the pressure of rapid urbanization in Turkey. The main aim of this article is to explain how we implemented a participatory urban design guidance (PUrDeG) model for cultural heritage sites, which was developed as part of a research project. We explain how we used various techniques to engage various actors in preparing urban design guidelines for a cultural heritage site. In addition, the article discusses the importance of community engagement techniques and processes in developing urban design guidance, and the context of guidelines for sustainable conservation of cultural heritage sites with examples from the United Kingdom and Turkey. It then presents a case study conducted in the Hanlar District, a Unesco world heritage site in Bursa, Turkey. The case study includes research on planning decisions, site analysis, a survey of urban residents, in-depth interviews with local artisans, and an urban design workshop with various actors. The main outcomes of this study include a presentation of how to use various community engagement techniques to prepare urban design guidelines for cultural heritage sites in Turkey, an urban design guidance system for Bursa, and a list of recommendations related to urban design guidelines for the Hanlar District and Bursa in the light of UK experience.

Keywords: urban design guidelines, cultural heritage, community engagement, Unesco world heritage sites, Hanlar District 


\section{Introduction}

Cultural heritage sites have many sociocultural and socioeconomic values that enable communities to relate to their past, and they have great importance in maintaining urban identity and memory. However, rapid urbanization due to population growth, urban regeneration, or traffic or tourism pressure, which are currently common problems for many cities, is harming the authenticity and integrity of heritage sites in urban centres (Hassler et al., 2002; ICOMOS, 2005; Van Oers, 2010; Aksoy \& Enlil, 2012; Brombach et al., 2013). In addition, the lack of a holistic system of sustainable planning, conservation, and design, and especially the lack of essential community engagement and urban design tools, are threatening the sustainability of heritage sites in developing countries by causing the quality of public life and space.

Today, heritage studies are focused on sustainable conservation and development strategies in which community engagement and urban design tools play important roles (Özcan, 2009). Within this context, statutory or discretional urban design guidelines need to be designed and implemented to conserve the contextual uniformity, continuity, and authenticity of cultural heritage sites (Tiesdell et al., 1996). Urban design guidelines are mostly described as supplementary planning documents that provide additional information and guidance in design matters. They explain how specific types of development can be carried out in accordance with a plan's design policies. A guideline explains a set of design principles relating to that topic, defines common design failings and helps avoid them, and supports local authorities in communicating with everyone involved in the development process for negotiation (DETR, 2000). Especially in heritage sites, central and local governments carry out urban development following urban design guidelines to preserve local characteristics (Madanipour, 1996; DETR \& CABE, 2000). The guidelines should be developed in the context of every specific city, district, or heritage site (Von Hausen, 2013). At this point, community engagement is crucial in preparing design guidelines to raise the capacity of local communities, to improve design proposals in historical places, to help create consensus between related actors so that planning applications can be processed more smoothly and quickly, and to help engender a sense of community and social bonds among the local community (Yeang, 2000).

Many studies emphasize the importance of community engagement in urban design studies for sustainable urban conservation of heritage sites. For example, Carmona (2009) stresses that one of the ten universal principals of urban design is self-sufficiency, which requires community engagement in urban design. Nasser (2003) states that reuniting urban form with the activities and uses that take place within them and integrating land-use planning with local needs and aspirations are very crucial for holistic community development at heritage sites. Elnokaly and Elseragy (2013) explain that, sustainable urban conservation requires maintaining the typical urban tissue and essential qualities of the historic sites and the life of the communities residing there while adapting the physical structures and activities to some contemporary requirements. Križnik (2018) also emphasizes the need for citizen participation to ensure social cohesion for sustainable urban regeneration and urban redevelopment of deprived urban areas.

The main aim of this study is to explain how the authors implemented the participatory urban design guidance $(\mathrm{PUrDeG})$ model, which was developed as part of a research project conducted in the Hanlar District, which is a Unesco world heritage site in the city of Bursa. Three hypotheses are discussed in this article:

- Urban design tools have important roles in sustainable conservation of cultural heritage sites in developed countries;

- Community engagement is an integral part of planning and urban design in developed countries; and

- Different types of urban design guidelines are required to sustain the Hanlar District of Bursa.

In addition, two of the actions defined in the Bursa and Cumalıkızık Management Plan were carried out as part of this study. One of these is developing urban design guidelines specific to the management sites in order to preserve local characteristics in accordance with urban design principles. The other one is balancing cultural values and socioeconomic status by ensuring the active participation and cooperation of the public to increase the quality of life (Bursa Site Management Unit, 2013).

\section{Experiences from the UK: Urban design and community engagement tools at cultural heritage sites}

Design governance tools are categorized as formal (legally defined by statute) or informal (discretional/non-statutory) tools. Formal tools are categorized as guidance, incentive, and control, and informal tools range from the gathering of evidence to the dissemination of knowledge through the active promotion of design, the evaluation of design quality, and finally direct assistance with projects and/or design through the lens of the Commission for Architecture and the Built Envi- 
Table 1: Community engagement process and methods in preparing design tools, UK examples.

\begin{tabular}{|c|c|c|c|}
\hline Tool & Status & Consultation and engagement methods & $\begin{array}{l}\text { Community engagement tools and } \\
\text { consultation }\end{array}$ \\
\hline $\begin{array}{l}\text { Liverpool supple- } \\
\text { mentary planning } \\
\text { documents (SPDs) }\end{array}$ & $\begin{array}{l}\text { Not included under } \\
\text { term local plan. He- } \\
\text { Ips applicants make } \\
\text { successful applica- } \\
\text { tions }\end{array}$ & $\begin{array}{l}\text { E-mail /written notification to statutory con- } \\
\text { sultees, documents on LCC website for gene- } \\
\text { ral comment, press release and public notices, } \\
\text { dissemination of electronic material through } \\
\text { umbrella organizations, tailored meetings }\end{array}$ & $\begin{array}{l}\text { Liverpool Statement of Community Involve- } \\
\text { ment: four-week consultation. } \\
\text { - Informal scoping consultation } \\
\text { - Publish draft SPD for comment } \\
\text { - Adopt SPD }\end{array}$ \\
\hline $\begin{array}{l}\text { Bath supplemen- } \\
\text { tary planning } \\
\text { documents }\end{array}$ & $\begin{array}{l}\text { Supplement policies } \\
\text { contained in DPDs, } \\
\text { must follow statutory } \\
\text { process, not subject } \\
\text { to formal examina- } \\
\text { tion }\end{array}$ & $\begin{array}{l}\text { Media, notification by letter /e-mail, area } \\
\text { notifications, local newspapers / publicity, } \\
\text { internet, hotline, seminars and lectures, public } \\
\text { inspection, formal and informal dialogues, } \\
\text { meetings and interactive workshops, surveys, } \\
\text { steering/advisory / working groups, discus- } \\
\text { sions with individuals and groups, internal } \\
\text { corporate discussions }\end{array}$ & $\begin{array}{l}\text { Bath and North East Somerset Statement of } \\
\text { Community Involvement: formal six-week } \\
\text { consultation. } \\
\text { - Informal community involvement in pre- } \\
\text { paring draft SPD } \\
\text { - Formal consultation on SPD } \\
\text { - Adoption by council }\end{array}$ \\
\hline $\begin{array}{l}\text { Edinburgh supple- } \\
\text { mentary guidance } \\
\text { and planning } \\
\text { guidelines }\end{array}$ & $\begin{array}{l}\text { In connection with } \\
\text { strategic or local } \\
\text { development plans. } \\
\text { Supplementary gui- } \\
\text { dance forms part of } \\
\text { development plan. }\end{array}$ & $\begin{array}{l}\text { Survey Monkey questionnaire and analysis, } \\
\text { written responses from organizations and } \\
\text { individuals, design guidance blog, public / } \\
\text { stakeholder pamphlets, bus shelter adver- } \\
\text { tisement, workshops, panel presentation, } \\
\text { feedbacks }\end{array}$ & $\begin{array}{l}\text { Planning Advice Note: Community Engage- } \\
\text { ment: subject to publicity, four-week consul- } \\
\text { tation. } \\
\text { - VOiCE software to design and deliver } \\
\text { effective engagement. } \\
\text { Edinburgh Street Design Guidance Consultati- } \\
\text { on Report } \\
\text { - Establish scope of review } \\
\text { - Awareness raising/testing } \\
\text { - Circulate draft for consultation } \\
\text { - Awareness raising and reviews } \\
\text { - Road testing the guidance }\end{array}$ \\
\hline
\end{tabular}

Source: LCC (2013); B\&NESC (2007); CEC (2018c); The Scottish Government (2010).

ronment (CABE) in the UK (Carmona, 2017). Design guidelines can be described as statements that specify how to meet design objectives (Lang, 1996) based on urban design issues such as the district-context relationship, the scale-character relationship, the public-private space balance and quality, the accessibility-permeability relationship, the density-use relationship, mixed use and typology, and sustainable structures and environments. In line with these issues, objectives of urban design such as maintaining character, continuity and enclosure, the quality of public space, accessibility, legibility, adaptability and harmony, diversity, and ecological balance should also be achieved (DETR \& CABE, 2000; Yeang, 2000; Punter, 2007; Von Hausen, 2013).

There are many types of design guidance based on the objectives of urban design. Carmona (2011) defines four types of formal design guidance with a different degree of locational specificity and interpretation. These are design standards (generic, prescriptive), design coding (site-specific, prescriptive), design policy (generic, performance-based), and design frameworks (site-specific, performance-based). In addition to these, practice guides, which refer to the sorts of informal guidance on generic aspects of urban design/development practice and are created to share best practice, either in process or outcomes, are also widely used in the UK (Cowan, 2002; CABE, 2003; Ministry of Environment and Urbanization \& Mimar Sinan Fine Arts University, 2016; Carmona, 2017).

Many categories of guidance and tools are used in planning practice in the UK. Guidance on design provides advice on the key design points to take into account while defining planning processes and tools. UK policy statements and legislation also encourage community engagement in design, heritage, and planning issues. English local authorities develop statements of community involvement (SCIs) to engage the local community in the development of planning policy and the determination of planning applications (Royal Town Planning Institute \& Consultation Institute, 2005).

In Liverpool and Bath, community engagement is guaranteed by statements of community involvement (SCIs) which explain the process, methods, and other details of community involvement in preparing the local development framework, including development plan documents (DPDs) and supple- 
mentary planning documents (SPDs), and in the consideration of planning applications (B\&NESC, 2007; LCC, 2013). SPDs provide additional details to show how policies in development plan documents should be implemented. These include design guides, development briefs, and topic-based papers. Community engagement in the preparation of SPDs is mainly summarized in three phases: informal scoping consultation, formal consultation on the draft SPD, and preparation and adoption of the final SPD. A range of methods are used for consultation and engagement (Table 1; B\&NESC, 2007; LCC, 2013). In Liverpool, SPDs - which must be consistent with national planning policy and conform to regional and local planning policy - have formal status as part of an area's planning framework. The Liverpool Maritime Mercantile City World Heritage Site SPD aims to raise standards of design and conservation and to provide guidance for protecting and enhancing the outstanding universal value (OUV) of the WHS while encouraging investment and development that secures a healthy economy and supports sustainable regeneration for all relevant stakeholders (LCC, 2009). In Bath, there are also various SPDs that are formerly adopted by a council resolution and can be a material consideration in planning decisions (B\&NESC, 2018). The Bath City-Wide Character Appraisal SPD aims to identify key elements of character by highlighting variations across the city (B\&NESC, 2005). The City of Bath WHS Setting is another SPD that provides information and the tools needed for effective protection and appropriate management of the setting (B\&NESC, 2013). The Streetscape Manual SPD is developed to guide the selection, design, installation, and care of the district's streetscape and its historic preservation (B\&NESC, 2005). In addition to these, the Pattern Book for Bath's public realm (two volumes) sets out the framework for the quality of streets and public spaces in the city centre (B\&NESC, 2015).

In Scotland, in addition to legislation, specific advice notes and guidance on community engagement are also available from a variety of sources (Royal Town Planning Institute \& Consultation Institute, 2005). If supplementary guidance is to be adopted as part of the development plan, public consultation is a legal requirement (The Scottish Government, 2010). In Edinburgh, there are two categories of guidance. Supplementary guidance provides further details on policies in the adopted Edinburgh Local Development Plan, and planning guidelines provide advice on a range of topics to guide new development (CEC, 2018a). The Edinburgh Standards for Urban Design are set out as urban design principles and are shown within a hierarchy that comprises the citywide, local area, site / street, and public realm dimensions (CEC, 2003). The Edinburgh Design Guidance sets out the council's expectations for designing new developments in Edinburgh to achieve the highest quality of design and to integrate well with the existing city (CEC, 2018b). The Edinburgh Street Design Guidance, which aims to coordinate street design and to promote collaboration between different disciplines, is a user-focused, non-statutory guidance document (CEC, 2015). Another guidance on listed buildings and conservation areas provides information on repairing, altering, or extending listed buildings and unlisted buildings in conservation areas (CEC, 2019).

As seen, England and Scotland are prominent examples that developed, defined, and experienced urban design and community engagement tools as key parts of their planning and urban design legislation and professional practice. In both countries, different types of design tools that support each other have been established from the national scale to the local scale for heritage sites. Tools adopted as part of a development plan have formal status as a supplementary planning document/ guidance for which public consultation is required. There is also guidance that explains how to conduct community engagement and which tools should be used during planning, design, and conservation (Table 1). In addition, there are many public bodies, charities, and initiatives that support and guide community engagement in the UK.

As a result, UK experiences showed that urban design tools have important roles in sustainable conservation of cultural heritage sites, and community engagement is an integral part of planning and urban design in developed countries. Thus, the first and second hypotheses of this study were confirmed. The examination of urban design and community engagement tools in the UK provided lessons for the community engagement techniques in preparing urban design guidelines and developing an urban design guidance system for Bursa.

\section{Community engagement and urban design guidance in the Turkish planning system}

The planning system in Turkey is subject to Development Law no. 3194, adopted in 1985. In this law and its regulations, there is no definition of community engagement and urban design within the planning system. Within the scope of the Ninth Development Plan, the Integrated Urban Development Strategy and Action Plan (KENTGES) was prepared in 2010 to raise living standards and to strengthen the economic, social, and cultural structures of cities. The need for community engagement and urban design guidelines was first defined in this document in the Turkish planning system (MPWS, 2010). After the establishment of the Department of Urban Design within the scope of the Ministry of Environment and Urbanization General Directorate of Spatial Planning in 2013, studies to develop the practice of community engagement 
and the preparation of urban design guidelines have accelerated (MPWS, 2010).

In the same period, Regulation of Development Law no. 3194 was amended in 2014, and the principles of urban design projects were defined in the Regulation for the Preparation of Spatial Plans. It was also stated that urban design guidelines should be prepared to develop the urban image, meaning, and identity, to raise the aesthetic and artistic value of spaces, and to arrange the buildings in a harmonious way in the direction of the urban design projects. However, a study by Rezafar and Turk (2018) showed that many factors related to urban design and aesthetic assessment are lacking in the Development Law and in Turkish planning legislation. Thus, they defined which parameters, in accordance with their scope, can be incorporated into legislation at the national level, city/town level, and local level including design guidelines in their study.

In addition, the regulation does not include any direct reference to community engagement in planning. However, it emphasizes that approved environmental plans and local plans must be announced to the public to receive comments within thirty days, all types of plans and their supplements must be open to the public, the media, and electronic communications, and seminars, conferences, exhibitions, and meetings can be used to inform the public about the plans. In addition, the Instruction for the Preparation and Evaluation of Urban Design Projects to be Approved by the Ministry of Environment and Urbanization (2015) states that one of the objectives of urban design projects is to facilitate public negotiation by informing residents, professional chambers, and non-governmental organizations about urban design projects by setting up meetings with mukhtars, holding press briefings, and so on, and to conclude the process with reports by reviewing their opinions and recommendations. However, the instruction does not present any engagement method to facilitate public negotiation. At present, studies to develop the practice of community engagement and the preparation of urban design guidelines are in progress at the ministry in cooperation with professional chambers, universities, and non-governmental organizations. In the near future, the ministry will require the municipalities to develop urban design guidelines.

While these studies were being carried out by various public institutions, the authors realized that there is a gap in studies about sustainable urban conservation of heritage sites in the context of using urban design tools. Thus, the authors started a research project called An Urban Design Guide Model for the City Centre of Bursa at Bursa Uludağ University in 2012. This project aims to develop a participatory urban design guidance (PUrDeG) model for cultural heritage sites, and a case study was carried out in the Hanlar District of Bursa in the context of this project between 2012 and 2015.

\section{Materials and methods}

Bursa (Figure 1) is the fourth-largest city of Turkey, and it is located in the Southern Marmara region, with a population of 2,936,803 (in 2017). It has always been an important centre of civilization, dating back to $6500 \mathrm{BC}$. The city of Prusa (modern-day Bursa) was founded in 185 BC by the Bithynians. After Roman and Byzantine rule, Bursa was conquered by Sultan Orhan in 1326 and became the capital of the Ottoman Empire (Bursa Site Management Unit, 2013).

Bursa and Cumalıkızk was nominated as a Unesco cultural heritage site in 2014 based on four cultural criteria (Bursa Site Management Unit, 2013). It was a serial nomination of eight world heritage sites (in six buffer zones; Figure 1), which illustrate the creation of the urban and rural system of the Ottoman Empire (Bursa Site management Unit, 2013). The Hanlar District (Figure 1) is one of the cultural heritage sites in the city centre of Bursa. It was established on the caravan roads and in the foothills of Uludag in the fourteenth century as a trade centre of which there are many examples of monumental and civil architecture (inns, mosques, public baths, bazaars, etc.) with well-preserved integrity and authenticity, such as the Orhan Ghazi complex. The district reflects the urban identity of Bursa with its original urban and architectural character and traditional trade life.

\subsection{Research methodology}

This study is a part of a research project that aimed to develop a PUrDeG model for the city centre of Bursa. However, this article does not focus on how the model was developed by the project team; it presents the local community engagement methods used in preparing urban design guidance for Bursa's Hanlar District based on the UK practice. The article also presents the model itself (Figure 2) to define the phases implemented during the case study.

The methodology of the research is composed of three phases, which are also included in the model. In the analysis phase, research on current development and management plans and urban design studies of the Hanlar District, site analysis, a survey of urban residents (users), and in-depth interviews with local artisans were conducted from the perspective of the urban design issues and objectives of the Bursa and Cumalıkızk Management Plan. In the synthesis phase, the results of the analyses were evaluated and urban design problems and the expectations of users and local artisans were categorized. In the 


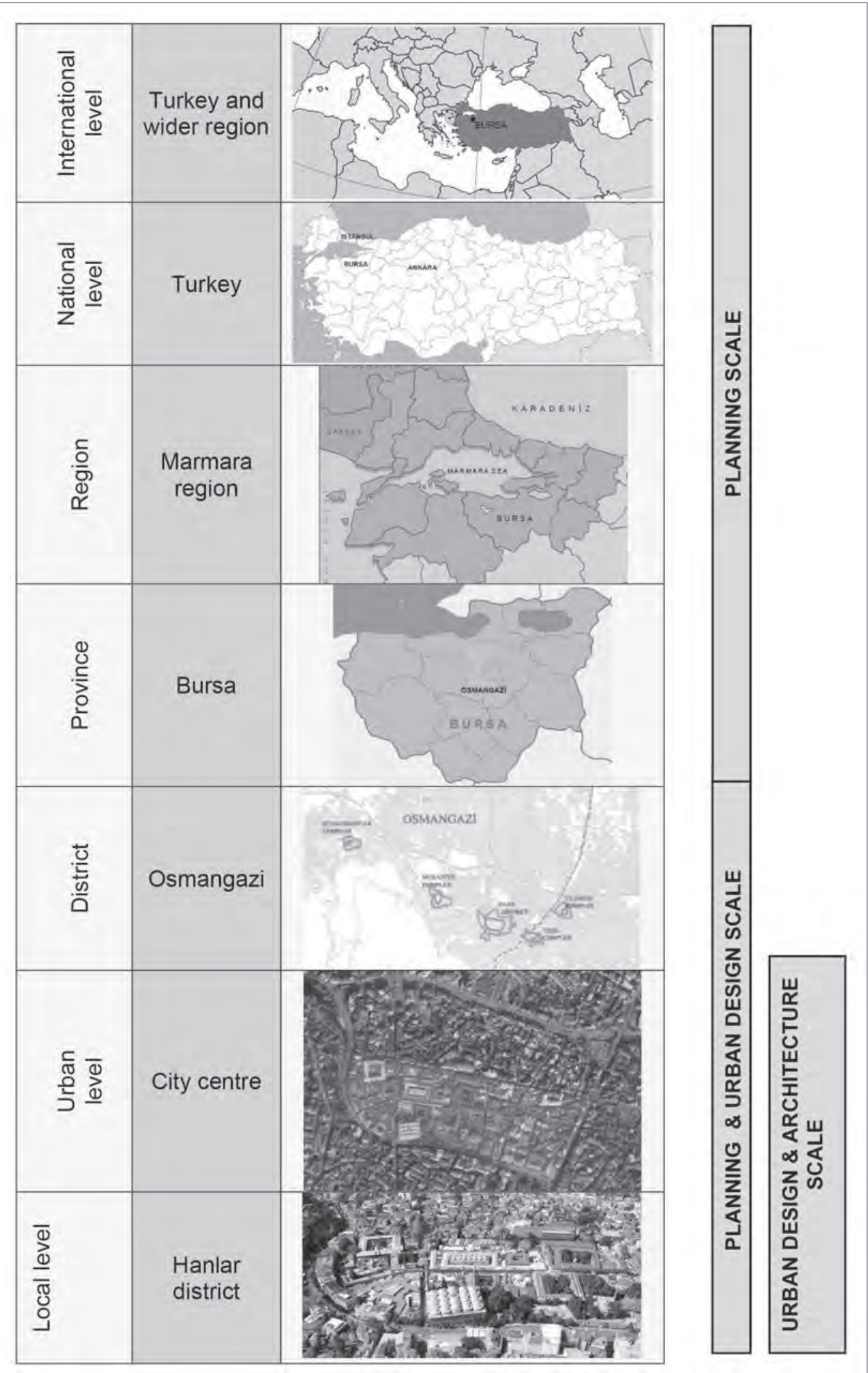

Figure 1: Location of the case study area at various planning scales (source: Bursa Site Management Unit, 2013; illustration: authors). 


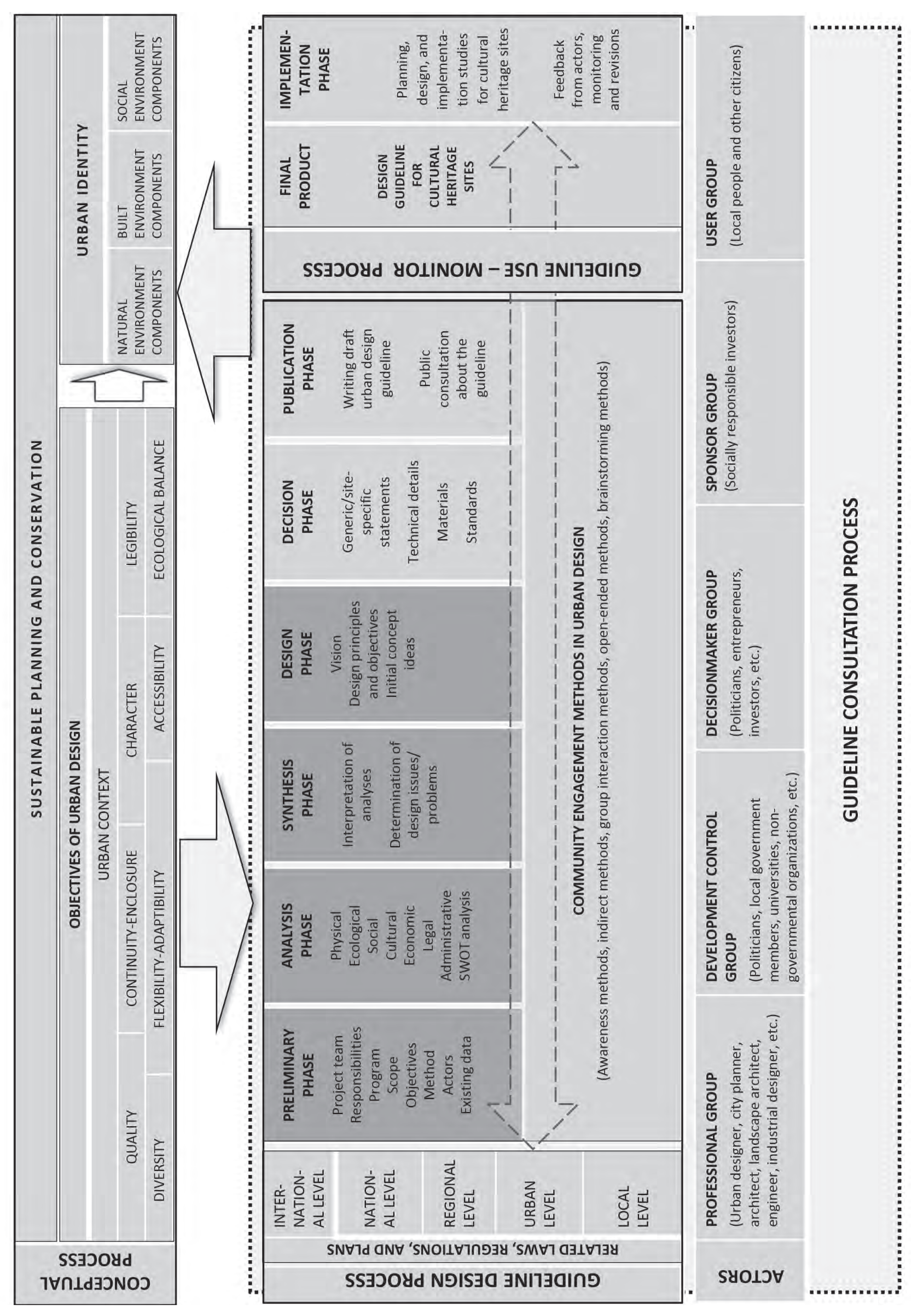

Figure 2: PUrDeG model for cultural heritage sites (source: Polat et al., 2018). 


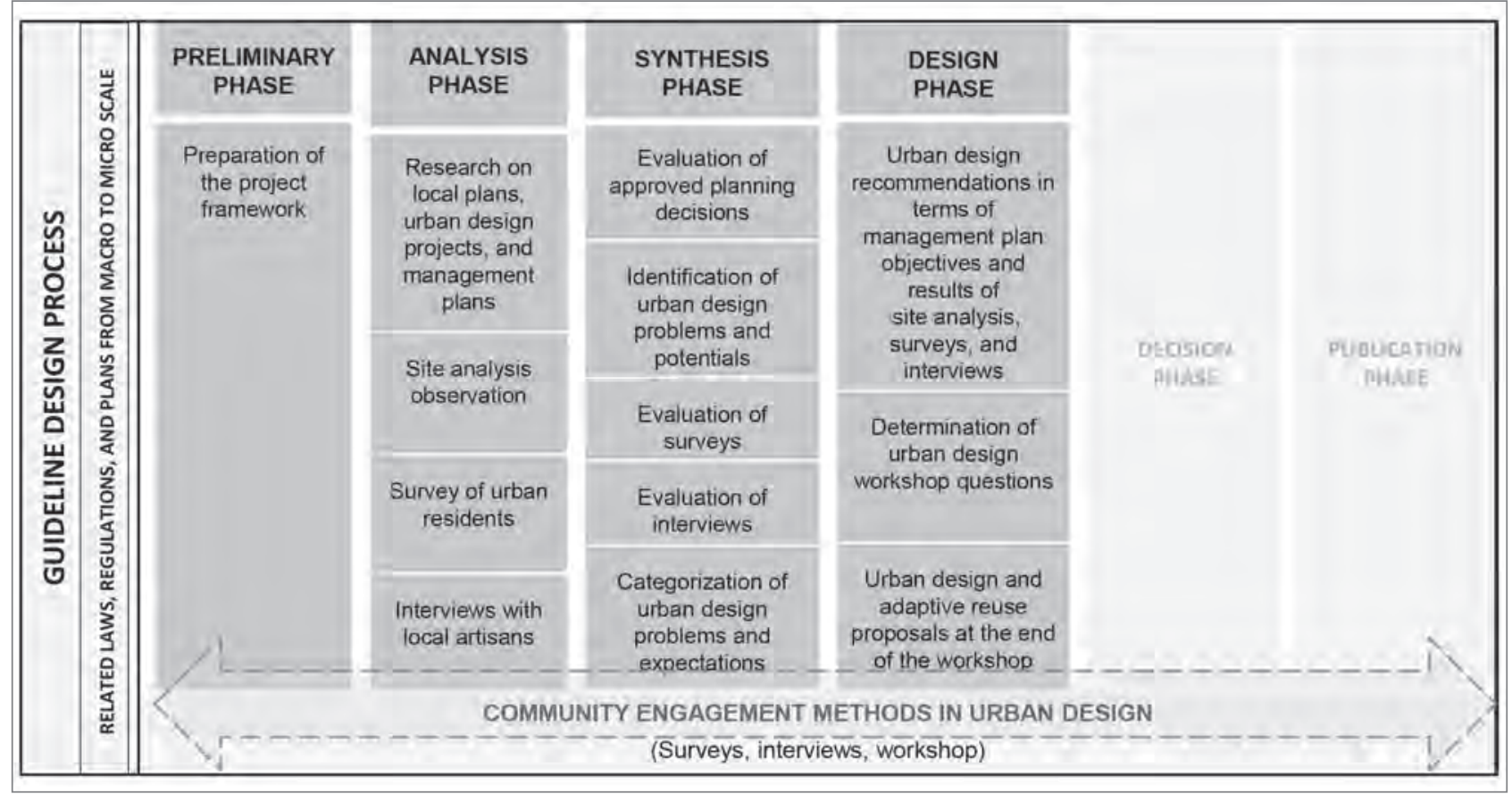

Figure 3: Implementation of the PUrDeG model in the Hanlar District (illustration: authors).

design phase, the urban design recommendations were developed to solve the problems and meet the expectations of the district, and a participatory urban design workshop was held in which architecture students developed urban design projects for idle public spaces in the Hanlar District. Thus, this case study allowed the project team to develop the PUrDeG model to sustain cultural heritage sites (Figure 3).

The model includes four basic processes (conceptualization, guideline design, guideline monitoring, and guideline consultation) to develop and implement an urban design guideline. Conceptualization is based on urban design issues and urban identity elements in terms of sustainable urban conservation. Guideline design is based on urban design. It is composed of six interrelated steps (preliminary, analysis, synthesis, design, decision, and publication phases). Guideline monitoring includes receiving feedback and making revisions during the use of the guideline. Guideline consultation is based on the identification of actors and community engagement techniques in urban design, and is carried out with the other three processes (conceptualization, guideline design, and guideline monitoring). All of these are interrelated, flexible, and adaptive to feedback (Polat et al., 2018).

\subsection{Evaluation of the approved planning decisions}

The Reyhan-Kayhan-Hanlar District was declared an urban conservation area in 1986 due to its historical qualities. Stra- tegic, master, and local plans have been approved for this area, including the Hanlar District. The main objective of the 2020 Environmental Plan for Bursa (scale: 1:100,000, adopted in 1998) was the conservation, rehabilitation, and restoration of the historical centre, which is located in the central planning area, while supporting service sector growth in the district by 2020. No density increase was allowed. In the Bursa Central Area and Reyhan-Kayhan-Hanlar District Preservation Plan (scale: 1:1,000, 1988-2005), seven special project areas were identified in the Hanlar District. In special project areas, any kind of construction activities (renovation, repair, reconstruction, etc.) can only be implemented as part of restoration, adaptive reuse, and urban design projects approved by the Bursa Cultural and Natural Heritage Preservation Board. However, no urban design projects or tools have been developed for the Hanlar District so far. Although an urban design competition for Orhangazi Square and its surroundings in the Hanlar District was arranged in 2012, the first-prize project was not implemented.

With the foundation of the Bursa Site Management Unit, the Unesco nomination of Bursa began, and the Bursa and Cumalıkızık Management Plan was prepared in 2013 with a participatory approach. The plan sets out objectives and actions related to the problems of the heritage sites. The main problems of the Hanlar District can be summarized as the lack of a holistic conservation approach for the district, the lack of a common database for sharing information between institutions, old and inadequate local conservation plans, physical 
and functional dilapidation, the lack of user diversity, the lack of a common architectural language between the new developments and historical urban pattern, and too many illegal additions to the historic buildings, which overshadow their original architectural character. These problems can be grouped under the following five urban design issues: governance and engagement (during urban design), the accessibility - permeability relationship, the scale - character relationship, sustainable structures and environments, and mixed-use balance. Thus, the proposed design guidance should address these urban design issues to ensure the sustainability of the Hanlar District.

\subsection{Site analysis results}

The project team faced similar problems and potentials as in the management plan during the site analysis. Many problems and potentials were observed from the city scale to the building scale. The main problems are related to the lack of spatial quality and mixed use, security problems at night, poor accessibility for pedestrians, and deterioration of the historic pattern. The problems can be grouped under the following five urban design issues: district - context relationship, scale-character relationship, public - private space balance and spatial quality, accessibility - permeability relationship, and mixed-use and typology balance. The district also has many potentials, such as being a Unesco world heritage site with its historical and cultural qualities, being an easily accessible location in the city centre, and having some vacant lots that can be used for infill development opportunities. However, to allow community engagement, urban residents and local artisans in the Hanlar District were also included in the other phases of the case study.

\subsection{Survey results}

As part of the case study, a survey of urban residents was conducted. The main aim of the survey was to analyse the Hanlar District in terms of basic urban design issues (i.e., establishing district-context and scale-character relationships, public-private space balance and quality, accessibility - permeability and density - use relationships, mixed-use and typology, and creating sustainable structures and environments). Thus, the main issues that should be considered in the proposed design guidance could be determined. The target population of the survey was shopping mall users. Today many urban residents prefer spending time at shopping malls rather than in city centres. Thus, many city centres become abandoned and suffer from urban decay. Therefore, the survey was designed to measure the perceptions, satisfaction levels, and expectations of shopping mall users from the Hanlar District to attract them to the city centre.
The survey was carried out in the four largest shopping malls in Bursa, one of which is the biggest competitor for the Hanlar District because of its location in the city centre. The survey was applied to 370 volunteer users at the malls. Those who had lived in Bursa for less than a year, tourists, and non-volunteers were not included in the survey. There were thirty-four questions in the survey, and it took approximately ten to twelve minutes to complete. The first part of the survey was about user profile. The most important problem was the lack of user diversity. The second part of the survey was based on questions about defining character elements and the image of the Hanlar District. The main problem was the lack of sense of belonging. Traffic, noise, chaos, and crowds in the district have negatively affected the image of the district and social interaction. The third part of the survey was composed of questions about habits, problems, and management of the Hanlar District. The most basic problems related to the district are traffic density, poor access to the district, rarity of visits, lack of parking, inactive public spaces in some of the restaurants, poor management and publicity of the district, and lack of awareness about nomination of the heritage site. The fourth and final part of the survey was based on questions about users' expectations about the Hanlar District. According to the results, the greatest demand is for new cultural activity areas, adaptive reuse of historic buildings, and new design proposals for idle public spaces in the district. As a result, it was shown that the problems and expectations of shopping mall users are focused on the following five urban design issues: accessibility - permeability relationship, scale - character relationship, mixed-use balance, public-private space balance and spatial quality, and district - context relationship.

\subsection{Results of in-depth interviews}

However, to evaluate the socioeconomic conditions of local residents, it was decided to conduct in-depth interviews with a group of local artisans working in various sectors in the Hanlar District. Twenty-two in-depth interviews were carried out in cooperation with the Association of Bursa Historical Bazaar and Hanlar District (BTCHBD), a non-governmental organization that aims to conserve the historical pattern of the district, to meet the current needs and requirements of social life in the district, and to make the Hanlar District a centre of attraction (BTCHBD, 2010). During the interviews, semi-structured interview forms were used, and the interviews took fifteen to twenty minutes. Artisans from various sectors were required to evaluate their profession in terms of their income level and customer profile and to express their expectations of the physical, economic, social, cultural, and functional factors related to the district. The main problems of the district, according to interviews, are the following: 
- Lack of cooperation between the institutions and local artisans (lack of proper authorization, lack of engagement, lack of promotional opportunities for the district, poor education facilities for local artisans, etc.);

- Barriers to restoration and reuse projects because of the high rates of private ownership;

- Lack of customer diversity and quantity (due to a lack of mixed-use areas and security concerns, low purchasing power, and low attractiveness of the bazaar together with new shopping malls in sub-centres of the city growing to the west, mostly domestic and Middle Eastern tourists); and

- Lack of transportation and accessibility opportunities (inadequate transfer points, lack of pedestrian routes, and lack of parking areas).

As a result, it was shown that the problems and expectations of local artisans are focused on the following five urban design issues: governance and engagement (during urban design), mixed-use balance, scale - character relationship, accessibility-permeability relationship, and sustainable structures and environments.

\subsection{Urban design workshop results for the Bursa city centre}

In accordance with the management plan objectives and the urban design recommendations developed as a result of the surveys and interviews, a participatory urban design workshop was held to search for public development opportunities for various areas in the Hanlar District similar to concept designs in the guidelines for Bath and Liverpool.

The workshop discussed concept design projects for idle public spaces in the Hanlar District while creating a participatory platform that brings together different actors such as the representatives of public institutions, local authorities, professional chambers, non-governmental organizations, local residents, architecture students, and the project team as the workshop coordinators. Most of the student proposals were related to adaptive reuse of the inns to allow the conservation of the traditional culture and character by hosting social and cultural events in the inns and public spaces, and the others were related to developing new green areas and high-quality public spaces in the city centre or to integrating contemporary architecture into the historical urban pattern. As a result, it was shown that the students focused on solving the following five urban design issues in their proposals: mixed-use and typology balance, district - context relationship, public-private space balance and spatial quality, accessibility - permeability relationship, and sustainable structures and environments. The workshop allowed local governors and other stakeholders to create new visions about heritage sites while developing urban awareness about the sustainability of heritage sites and use of community engagement tools.

\section{Discussion and recommendations}

In terms of the relationship between sustainable planning, conservation, urban design, and architecture, the study showed that different types of urban design guidelines are required to sustain the Hanlar District of Bursa. Thus, based on the examples from the UK, an urban design guidance system that confirmed the third hypothesis of the article was proposed for Bursa (Figure 4). The design guidelines for Bursa should be developed as formal supplementary planning documents by the Metropolitan Municipality of Bursa with a participatory approach. The guidance system is composed of three scales, which are presented below.

\section{Citywide design guidance:}

- Bursa citywide character appraisal should give an understanding of what makes Bursa distinctive by considering its character and significance.

- Bursa urban design standards should set out general urban design principles to maintain and improve the visual image and identity of Bursa and ensure that high-quality urban design is sought from new development across the entire city.

Local/thematic design guidance:

- Bursa downtown urban design and public space framework should be a prospectus that presents the physical form of the downtown and defines how it can be transformed over the coming decades.

- Bursa and Cumalıkızık heritage sites local development framework should provide thematic guidance for protecting and enhancing the outstanding universal value of the Bursa world heritage sites while encouraging investment and development that secure a healthy economy and support regeneration.

Building / technical design guidance:

- Guidelines for conserving the local character of the Hanlar District can be related to streetscapes, listed buildings, landscape, lighting, pedestrian safety, and cycling.

However, to make the guidelines useful in practice for the Hanlar District, they should take account of expectations of the urban residents and the local artisans. As a result of the case study, the authors developed a matrix of failures in solving urban design issues and conducted five different analyses to establish which failures stood out in the Hanlar District (Table 2). 

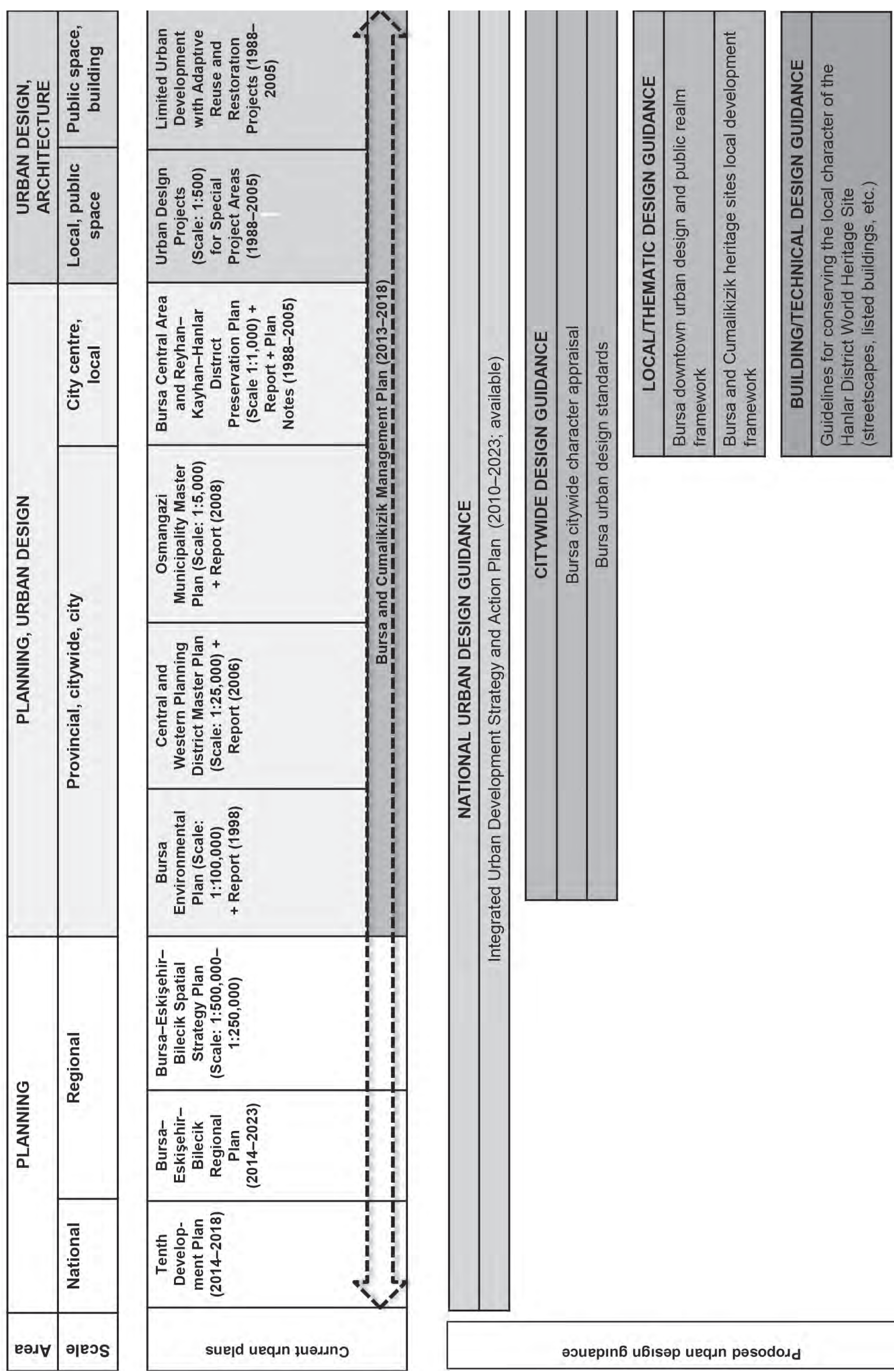

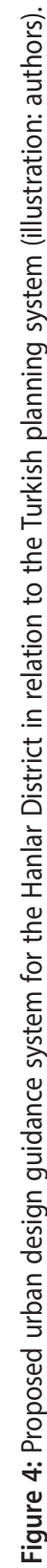


Table 2: Urban design issue (UDI) failures in the Hanlar District according to the case study.

\begin{tabular}{|c|c|c|c|c|c|c|}
\hline & Analysis & & & & & \\
\hline UDI failure & $\begin{array}{l}\text { Site management } \\
\text { plan decisions }\end{array}$ & $\begin{array}{l}\text { Site } \\
\text { analysis }\end{array}$ & Surveys & $\begin{array}{l}\text { In-depth } \\
\text { interviews }\end{array}$ & Workshop & Total \\
\hline District - context relationship & 2 & 5 & 3 & 1 & 4 & 15 \\
\hline Scale - character relationship & 4 & 5 & 5 & 4 & 3 & 21 \\
\hline Public - private space balance and quality & 2 & 4 & 4 & 2 & 4 & 16 \\
\hline Accessibility - permeability relationship & 5 & 4 & 5 & 4 & 4 & 22 \\
\hline Density - use relationship & 3 & 3 & 2 & 2 & 2 & 12 \\
\hline Mixed-use and typology balance & 3 & 3 & 4 & 5 & 5 & 20 \\
\hline Sustainable structures and environments & 4 & 2 & 1 & 3 & 3 & 13 \\
\hline $\begin{array}{l}\text { Governance and engagement (during urban } \\
\text { design) }\end{array}$ & 5 & 1 & 2 & 5 & 1 & 14 \\
\hline
\end{tabular}

Note: 1 - 5 = rarely-frequently mentioned

Source: authors.

Table 3: Recommendations about the process and context of developing urban design guidance for Bursa's Hanlar District.

\begin{tabular}{l} 
Scale and details \\
\hline National/regional scale: community engagement in preparing urban design guidelines \\
- Use different community engagement methods for preparing draft design guidelines \\
- Public consultation
\end{tabular}

Publish draft guidelines on municipality website

Present in public spaces (libraries, museums, main squares)

- Formal views

Disseminate draft guidelines to related institutions

- Gather comments

- Write public consultation report including municipality responses

- Publish consultation report

Provincial, citywide, city scale: development of an urban design guidance system for Bursa

- Objectives related to the district-context and accessibility-permeability relationship in proposed urban design guidance for the Hanlar District

Prepare a Bursa citywide character appraisal (as for Bath)

Develop Bursa urban design standards (as for Edinburgh)

- General urban design principles should be developed in a sequential relationship between different levels. To identify and unify urban identity at different scales, cultural heritage sites should be integrated into new development areas, citywide views and city edges should be protected, the image and the legibility of heritage sites should be improved, and the network of green and civic spaces should be strengthened and extended.

- According to urban residents, new pedestrian routes to strengthen north-south and east-west connections should be identified, pedestrian-vehicle interactions should be prevented, the legibility of tourist routes and access to underpasses should be increased, and new parking spaces integrated with public transport should be created.

- According to local artisans, height and mass limits for new buildings should be defined to preserve the natural appearance of Bursa and the historical silhouette and the human scale of the Hanlar District. 


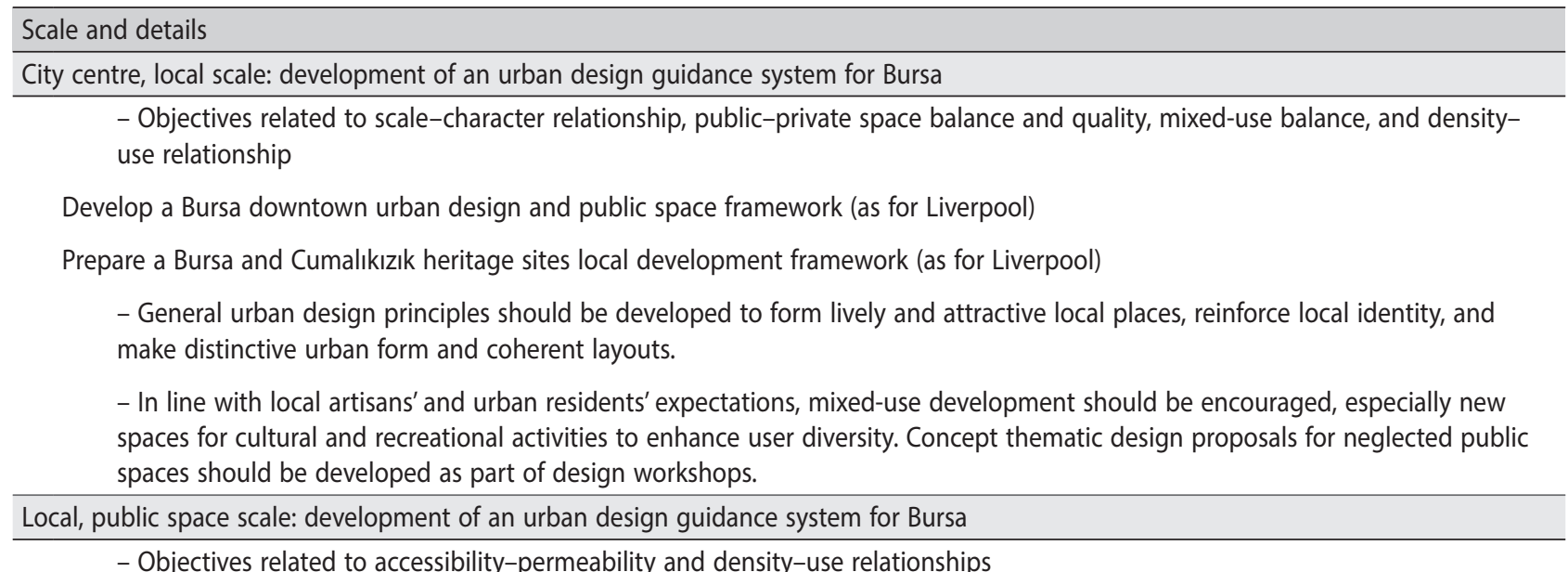

Develop a Bursa downtown urban design and public space framework (as for Liverpool)

Prepare a Bursa and Cumalıkızık heritage sites local development framework (as for Liverpool)

- To increase pedestrian accessibility of the Hanlar District, standards for streets, pavements, pedestrian crossings, and ramps should be set out in line with universal design principles.

- In line with the expectations of local artisans and urban residents to develop pedestrian-oriented streets that are active twenty-four hours a day with strong local features, regulations that increase spatial comfort such as quantitative and qualitative standards for service facilities (tourism information, toilets, baby-care rooms, etc.) and urban furniture (lighting, seating elements, etc.) should be created.

Public, building scale: development of an urban design guidance system for Bursa

- Objectives related to scale-character relationship, and sustainable constructions and environments

Develop detailed guidelines to conserve the local character and distinctiveness of the Hanlar District (as in Bath, Liverpool, and Edingburgh)

- To conserve the authentic identity of historical buildings, and to restore and renovate them in line with current requirements, general principles related to proper repair, and external and internal alterations to listed buildings should be determined.

Source: authors.

These findings allowed the authors to develop a table of recommendations regarding the process and context of developing guidelines for Bursa's Hanlar District according to the authors', urban residents' (shopping mall users), and local artisans' perspectives and examples from the UK (Table 3).

\section{Conclusion}

The main contribution of this study is the integration of various community engagement techniques in the preparation of design guidelines. If the community is engaged from the very beginning, local authorities can overcome challenges more easily while developing urban design guidance, as seen in the UK examples. In this study, the main sample group was shopping mall users and the local artisans. The community in Bursa is made up of various groups, some of which face difficulties participating in heritage studies. These are hardto-reach groups that comprise minority ethnic groups, young people, the elderly, transient populations such as new residents, commuters, and students, Roma, people with disabilities, and single parents. Thus, it is important to engage hard-to-reach groups in urban studies.

In addition to these, significant conclusions are also drawn for Bursa and Turkey based on how the legislative framework about community engagement in preparing urban design guidance is developed and used in the sustainable conservation of heritage sites in the UK. First of all, legal documents explaining how to conduct community engagement in planning and urban design should be prepared, such as statements of community involvement. It is also important to define urban design tools legally in developing countries like Turkey. Because urban design practice is still in progress, local authorities' experience is limited, and users' awareness is inadequate in Turkey. In this study, various community engagement techniques were used to involve related actors. However, if public consultation is conducted electronically by local authorities, it can be more accessible and completed more quickly, and the comments can be evaluated more efficiently and practically. In addition, it is 
necessary to define the methods of supervision and monitoring, as well as how to obtain feedback on whether the advice in the guidelines for the Hanlar District is implemented. A board of experts in the Bursa Site Management Unit can carry out this supervision. Education-awareness activities with urban residents and local artisans and awarding successful implementations can also be useful for encouraging the use of guidelines.

Considering that there are eighteen Unesco world heritage sites in Turkey, it is obvious that there is a need for systematic approaches in heritage studies. Design guidelines for these sites should be developed with site management plans in a coordinated way. Therefore, this study contributes to the development of urban design guidelines by presenting how to implement the PUrDeG model for cultural heritage sites.

Sibel Polat

Bursa Uludağ University, Faculty of Architecture, Department of Architecture, Bursa, Turkey

E-mail: sibelpolat@uludag.edu.tr

H. Özge Tümer Yıldız

Bursa Uludağ University, Faculty of Architecture, Department of

Architecture, Bursa, Turkey

E-mail: ozgetumer@uludag.edu.tr

\section{Acknowledgements}

This work was funded as a scientific research project (Project number: OUAP(M) - 2012/24) conducted at Bursa Uludağ University.

\section{References}

Aksoy, A. \& Enlil, Z. (2012) Kültürel miras yönetiminde çağdaş yaklaşımlar. In: Aksoy, A. \& Ünsal, D. (eds.) Kültürel miras yönetimi, pp. 3-28. Eskişehir, Anadolu Üniversitesi Web-Ofset.

B\&NESC (2005) = Bath \& North East Somerset Council (2005) Streetscape manual. Available at: http://www.bathnes.gov.uk/sites/default/ files/sitedocuments/Planning-and-Building-Control/Planning-Policy/ SPDs/streetscape_manual_adopted.pdf (accessed 27 Feb. 2017).

B\&NESC (2007) = Bath \& North East Somerset Council (2007) Statement of community involvement. Available at: http://www.bathnes.gov.uk/ sites/default/files/sitedocuments/Planning-and-Building-Control/Planning-Policy/LDFGeneral/StatementofCommunitylnvolvement-AdoptedDocument.pdf (accessed 27 Feb. 2017).

B\&NESC (2013) = Bath \& North East Somerset Council (2013) City of Bath World Heritage Site setting. Available at: https://www.bathworldheritage.org.uk/sites/world_heritage_site/files/heritage/World\%20Heritage $\% 20$ Site $\% 20$ Setting\%20Supplementary\%20Planning\%20Document. pdf (accessed 27 Feb. 2017).

B\&NESC (2015) = Bath \& North East Somerset Council (2015) Bath Pattern book: Volume 01, Public realm framework. Available at: http:// www.bathnes.gov.uk/services/planning-and-building-control/major-projects/public-realm-and-movement/preparatory-projects (accessed 27 Feb. 2017).
B\&NESC (2018) = Bath \& North East Somerset Council (2018) Supplementary planning documents (SPDs) and other useful guidance. Available at: http://www.bathnes.gov.uk/services/planning-and-building-control/planning-policy/supplementary-planning-documents-spds (accessed 19 Jul. 2018).

Brombach, K., Simon-Philipp, C. \& Kurth, D. (2013) District centre regeneration - A European perspective. Proceedings of the Institution of Civil Engineers Urban Design and Planning. 166(DP4), pp. 229-240. DOI: 10.1680/udap.11.00007

Bursa Site Management Unit (2013) Bursa and Cumalıkızı: the Birth of the Ottoman Empire. Bursa, Bursa Metropolitan Municipality. Available at: http://alanbaskanligi.bursa.bel.tr/wp-content/uploads/unesco-adaylik-dosyasi-ve-ekleri-ingilizce-icin-tiklayiniz.pdf (accessed 19 Jul. 2018).

Carmona, M. (2009) Sustainable urban design: Definitions and delivery. International Journal for Sustainable Development, 12(1), pp. 48-77.

Carmona, M. (2011) Decoding design guidance. In: Banerjee, T. \& Loukaitou-Sideris, A. (eds.) Companion to Urban Design, pp. 288-303. London, Routledge.

Carmona, M. (2017) The formal and informal tools of design governance. Journal of Urban Design, 22 (1), pp. 1-36. DOI: 10.1080/13574809.2016.1234338

CEC (2003) $=$ The City of Edinburgh Council (2003) The Edinburgh standards for urban design. Edinburgh. The City Development Department, Planning \& Strategy.

CEC (2015) $=$ The City of Edinburgh Council (2015) Edinburgh street design guidance consultation report.

CEC (2018a) = The City of Edinburgh Council (2018a) Supplementary guidance. Available at: http://www.edinburgh.gov.uk/ info/20013/planning_and_building/64/supplementary_guidance (accessed 27 Feb. 2017).

CEC (2018b) = The City of Edinburgh Council (2018b) Edinburgh design guidance. Available at: http://www.edinburgh.gov.uk/downloads/ file/11650/edg_amended_october_2018 (accessed 28 Aug. 2018).

CEC (2018c) = The City of Edinburgh Council (2018c) Edinburgh street design guidance. Available at: http://www.edinburgh.gov.uk/downloads/download/550/edinburgh_street_design_guidance (accessed 28 Aug. 2018).

CEC (2019) = The City of Edinburgh Council (2019) Listed buildings and conservation areas. Available at: http://www.edinburgh.gov.uk/ downloads/file/4510/listed_buildings_and_conservation_areas (accessed 28 Aug. 2018).

Commission for Architecture \& the Built Environment (2003) The councillor's guide to urban design. Available at: http://www.designcouncil.org. uk/sites/default/files/asset/document/

councillors-guide-to-urban-design.pdf (accessed 2 Nov. 2017).

Cowan, R. (2002) Urban design guidance: Urban design frameworks, development briefs and master plans. London, Thomas Telford Ltd. DOI: $10.1680 /$ udg.31357

DETR \& CABE (2000) = Department of the Environment, Transport and the Regions \& Commission for Architecture and the Built Environment (2000) By design, urban design in the planning system: Towards better practice. Available at: https://www.gov.uk/government/ uploads/system/uploads/attachment_data/file/7665/158490.pdf (accessed 27 Feb. 2017).

Elnokaly, A. \& Elseragy, A. (2013) Sustainable heritage development: Learning from urban conservation of heritage projects in non western contexts. European Journal of Sustainable Development, 2, pp. 31-54. DOI: 10.14207/ejsd.2013.v2n1p31 
Hassler, U., Algreen-Using, G. \& Kohler, N. (2002) Cultural heritage and sustainable development in SUIT. SUIT position paper (3). Available at: http://www.lema.ulg.ac.be/research/suit/download/SUIT5.2c_PPaper. pdf (accessed 12 Nov. 2017).

ICOMOS (2005) Threats to world heritage sites 1994-2004: An analysis. Available at: https://www.icomos.org/world_heritage/Analysis\%20 of\%20Threats\%201994-2004\%20final.pdf (accessed 12 Nov. 2017).

Križnik, B. (2018) Transformation of deprived urban areas and social sustainability: A comparative study of urban regeneration and urban redevelopment in Barcelona and Seoul. Urbani izziv, 29(1), pp. 83-95. DOI: 10.5379/urbani-izziv-en-2018-29-01-003

Lang, J. (1996) Implementing urban design in America: Project types and methodological implications. Journal of Urban Design, 1(1), pp. 7-22. DOI: 10.1080/13574809608724368

LCC (2009) = Liverpool City Council (2009) Liverpool maritime mercantile city world heritage site supplementary planning document. Available at: http://liverpool.gov.uk/media/9644/world-heritage-site-spd.pdf (accessed 27 Feb. 2017).

LCC (2013) = Liverpool City Council (2013) Liverpool statement of community involvement. Available at: https://liverpool.gov.uk/council/strategies-plans-and-policies/environment-and-planning/plan-making-in-liverpool/statement-of-community-involvement/ (accessed 27 Feb. 2017).

Madanipour, A. (1996) Design of urban space: An inquiry into a socio-spatial process. Chichester, John Wiley and Sons Ltd.

Ministry of Environment and Urbanization (2015) Çevre ve şehircilik Bakanliğınca onaylanacak kentsel tasarım projelerinin hazırlanmasına ve değerlendirilmesine Ilişkin yönerge. Available at: https://kms.kaysis.gov.tr/ Home/Goster/131263 (accessed 28 Aug. 2019).

Ministry of Environment and Urbanization \& Mimar Sinan Fine Arts University (2016) Kentsel tasarım rehberleri cilt 1. Available at: http:// webdosya.csb.gov.tr/db/mpgm/editordosya/file/Kentsel\%20Tasarim/ Kentsel\%20Tasarim\%20Rehberleri/KENTSEL\%20TASARIM\%20REHBERLERI_Cilt1.pdf (accessed 27 Feb. 2017).

MPWS (2010) = Ministry of Public Works and Settlements (2010) Bütünleşik kentsel gelişme stratejisi ve eylem planı. (KENTGES) Available at: https://webdosya.csb.gov.tr/db/kentges/editordosya/kentges_tr.pdf (accessed 28 Aug. 2019).

Nasser, N. (2003) Planning for urban heritage places: Reconciling conservation, tourism, and sustainable development. Journal of Planning Literature, 17(4), pp. 467-479. DOI: 10.1177/0885412203017004001

Özcan, K. (2009) Sürdürülebilir kentsel korumanın olabilirliği üzerine bir yaklaşım önerisi: Konya tarihi kent merkezi örneği. ODTÜ Mimarlık Fakültesi Dergisi, 26(2), pp. 1-18. DOI: 10.4305/metu.jfa.2009.2.1

Polat, S., Tümer Yıldız, H. Ö. \& Dostoğlu, N. (2018) A user-oriented urban design guide model for cultural heritage sites: The case of Bursa Khans area. Megaron, 13(4), pp. 584-596. DOI: 10.5505/megaron.2018.32043

Punter, J. (2007) Developing urban design as public policy: Best practice principles for design review and development management. Journal of Urban Design, 12(2), pp. 167-202. DOI: 10.1080/13574800701306195

Rezafar, A. \& Turk, S. S. (2018) Urban design factors involved in the aesthetic assessment of newly built environments and their incorporation into legislation: The case of Istanbul. Urbani izziv 29(2), pp. 83-95. DOI: 10.5379/urbani-izziv-en-2018-29-02-002

Royal Town Planning Institute \& Consultation Institute (2005) Guidelines on effective community involvement and consultation. Available at: http://www.rtpi.org.uk/media/6313/Guidlelines-on-effective-community-involvement.pdf (accessed 27 Feb. 2017).
The Scottish Government (2010) Planning advice note 3/2010: Community engagement. Available at: http://www.gov.scot/Publications/2010/08/30094454/12 (accessed 27 Feb. 2017).

Tiesdell, S., Oc, T. \& Heath, T. (1996) Revitalizing historic urban quarters. London, Butterworth-Heinemann.

Van Oers, R. (2010) Managing cities and the historic urban landscape initiative - An introduction.. In: Van Oers, R. \& Haraguchi, S. (eds.) Managing Historic Cities; World Heritage Papers, 27, pp. 7-17. Paris, World Heritage Centre. Available at: http://whc.unesco.org/documents/ publi_wh_papers_27_en.pdf (accessed 10 Apr. 2017).

Von Hausen, M. A. (2013) Dynamic urban design. Bloomington, IN, iUniverse.

Yeang, L. D. (2000) Urban design compendium. Available at: http://www. queenelizabetholympicpark.co.uk/-/media/ldc/local-plan/local-plan-examination-documents/other-strategy-papers/s34-urban-design-compendium.ashx?la=en (accessed 27 Feb. 2017). 